URL: http://ojs.unimal.ac.id/index.php/ekonomi_regional

\title{
Pengaruh Inflasi, Pengeluaran Pemerintah dan Ekspor Terhadap Pertumbuhan Ekonomi di Indonesia
}

\author{
${ }^{*}$ Y Yusra Mahzalena, ${ }^{* b}$ Hijri Juliansyah \\ *Fakultas Ekonomi dan Bisnis Universitas Malikussaleh \\ a Corresponding author : yusramahzalena00@gmail.com \\ b hijri.juliansyah@gmail.com
}

\begin{tabular}{l}
\hline A R T I C L E I N F O R M A \\
Keywords: \\
Economic Growth, \\
inflation, Government \\
Expenditures, Exports.
\end{tabular}

\section{A B S T R A C T}

The purpose of this study is to determine the effect of inflation, Government spending, and exports on economic growth in Indonesia during 1990-2016. This study uses time series data obtained from the Central Bureau of Statistics. The study uses a Vector Autoregression Model (VAR) analysis. The results of the VAR analysis model showed that economic growth was insignificantly and positively influenced by its movements, inflation had a positive and insignificant effect on economic growth, and Government Expenditure had a positive and insignificant effect on economic growth, while exports had a negative and insignificant effect on economic growth.

\section{PENDAHULUAN}

Pada era presiden Soeharto menjabat kondisi ekonomi dan politik yang tidak baik. BPS mencatat pada tahun 1965 ekonomi Indonesia hanya tumbuh sebesar 1,08 persen. Ekonomi Indonesia selama kurun waktu 1960-1965 hanya tumbuh rata-rata dua persen. Periode 1966-1973 dapat dikatakan sebagai tahun transisi ekonomi. Dimana Soeharto mengambil kebijakan untuk memperbaiki keadaan ekonomi yang tengah merosot. Usaha perbaikan ekonomi tersebut terlihat pada taun 1968 dimana pertumbuhan ekonomi melambung tinggi ke level 10,91 persen.

Para era presiden Susilo Bambang Yudhoyono (SBY), cukup baik dalam menjaga pertumbuhan ekonomi. selama 10 tahun masa kepemimpinannya, pertumbuhan ekonomi melaju di kisaran lima hingga enam persen. Pencapain terendah pada tahun 2009 sebesar 4,63 persen yang dipengaruhui oleh tekanan ekonomi global yang berdampak pada pelemahan rupiah.

Ekonomi diera presiden Jokowi berkisaran di angka lima persen. Pertumbuhan ekonomi tercatat 4,90 persen pada tahun 2015. Tahuntahun berikutnya, angka tersebut tidak naik signifikan. tercatat pertubuhan ekonomi pada tahun 2015 sebesar 5,03 persen dan 2017 sebesar ,507 persen.

Penurunan tingkat inflasi juga dapat emnyebabkan pertumbuhan ekonomi meningkat yaitu pada tahun 2016. Sedangkan pengeluaran pemerintah yang menurun mengakibatkan pertumbuhan ekonomi menurun juga ikut menurun, tetapi malah berbanding terbalik dengan tahun 2016 yaitu pertumbuhan ekonominya meningkat sebesar 5,02 persen. Begitupun peningkatan ekspor diikuti pula dengan peningkatan pertumbuhan ekonomi..

Teori mengatakan bahwa pertumbuhan ekonomi ikut dipengaruhi oleh beberapa faktor seperti inflasi, belanja/pengeluaran pemerintah dan ekspor. Secara lebih jelas, kondisi variabel adalah sebagai berikut.

\section{Tabel 1}

Data Inflasi, Pengeluaran Pemerintah, Ekspor dan Pertumbuhan Ekonomi di Indonesia Tahun 2014-2016

\begin{tabular}{|c|c|c|c|c|}
\hline Tahun & $\begin{array}{c}\text { Inflas } \\
\text { i }(\%)\end{array}$ & $\begin{array}{c}\text { PP } \\
\text { (Milyar) }\end{array}$ & $\begin{array}{c}\text { Ekspor } \\
\text { (Milyar) }\end{array}$ & $\begin{array}{c}\text { PE } \\
(\boldsymbol{\%})\end{array}$ \\
\hline 2014 & 8,36 & 176.622 & $175.980,0$ & 5,02 \\
\hline 2015 & 3,35 & 233.281 & $150.336,3$ & 4,79 \\
\hline 2016 & 3,02 & 259.647 & $145.186,2$ & 5,02 \\
\hline
\end{tabular}

Sumber: BPS Indonesia, Bank Indonesia (2018)

Berdasarkan Tabel 1 di atas yaitu permasalahan terkait inflasi sejak tahun 2014 sampai tahun 2016 mengalami kondusi yang fluktuatif. Secara teori, menurunnya tingkat inflasi akan meningkatkan pertumbuhan ekonomi dan sebaliknya apabila tingkat inflasi meningkat maka 
pertumbuhan ekonomi akan menurun (Utomo, 2013). Namun yang terjadi di Indonesia pada tahun 2014 tingkat inflasi tinggi sebesar 8,36 persen, namun pertumbuhan ekonomi justru semakin baik yakni 5.02 persen. Sedangkan pada tahun 2015 tingkat inflasi rendah 3.35 persen namun pertumbuhan ekonomi juga ikut turun menjadi $4,79 \%$.

Meningkatnya inflasi tahun 2014 disebabkan peningkatan konsumsi barang jadi impor seperti elektronik dan sandang oleh masyarakat serta bahan baku impor oleh perusahaan di Indonesia. Namun, penggunaan bahan baku impor dapat mendongkrak produksi dalam negeri, hingga pendapatan nasional atau Produk Domestik Bruto (PDB) yang menjadi ukuran pertumbuhan ekonomi Indonesia mengalami peningkatan. Sedangkan pada tahun 2015, dimana tingkat inflasi rendah dan pertumbuhan ekonomi juga rendah disebabkan barang yang diproduksi dalam negeri tidak dapat terjual karena rendahnya pendapatan masyarakat akibat pendapatan sebagian penduduk seperti yang bekerja sektor pertanian mengalami gagal panen dan rendahnya harga jual hasil produksi petani.

Pada data pengeluaran Pemerintah pada tahun 2014 sampai tahun 2016 mengalami peningkatan setiap tahunnya. Meningkatnya pengeluaran pemerintah akan meningkatkan pertumbuhan ekonomi dan sebaliknya apabila pengeluaran menurun maka pertumbuhan ekonomi juga ikut menurun, namun yang terjadi di Indonesia tidak sesuai dengan teori tersebut, dimana ketika pengeluaran pemerintah sebesar tinggi yakni 259.647 milyar pada tahun 2016, namun pertumbuhan ekonomi lebih yakni tinggi sebesar 5,02\% dibandingkan dengan tahun 2014 yang pengeluaran pemerintahnya lebih tinggi yaitu 176.622 milyar, namun pertumbuhan ekonominya lebih rendah hingga mencapai $5,02 \%$.

Peningkatan pengeluaran pemerintah Indonesia khususnya barang modal tidak mampu mendongkrak pertumbuhan ekonomi, hal ini disebabkan barang modal yang dibelanjakan tidak berdampak secara langsung bagi perekonomian masyarakat dan merupakan aset yang kurang produktif. Kontradiksi dengan pembelanjaan barang modal tahun 2015, yaitu sebagian besar barang modal sebelumnya dan yang baru dialihkan untuk peningkatan produksi Badan Usaha Milik Negara (BUMN) dan Badan Usaha Milik Daerah (BUMD), hingga secara langsung terjadi peningkatan poduksi dalam negeri dan pendapatan masyarakat sebagai pekerja maupun sebagai produsen untuk kebutuhan barang dalam negeri.

Berdasarkan data di atas dapat dilihat bahwa ketika tingkat ekspor di Indonesia pada tahun 2015 sebesar $150.336,3$ juta US\$, namun pertumbuhan ekonomi lebih rendah dibandingkan tahun 2016 yakni 4,79\% berbeda dengan tahun 2016 yang nilai ekspornya hanya 145.186,2 juta US\$, namun pertumbuhan ekonomi lebih tinggi hingga mencapai 5,02\%. Secara teori, ketika ekspor meningkat maka pertumbuhan ekonomi juga ikut meningkat, tetapi justru ini terbalik dengan teori dimana pada tahun 2014 ekspor meningkat justru pertumbuhan ekonomi menurun.

Terjadinya penurunan nilai ekspor pada tahun 2016 disebabkan oleh permintaan barang dan jasa dari luar negeri mengalami penurunan, serta larangan eskpor bagi beberapa komoditi tertentu yang belum mampu mencukupi kebutuhan dalam negeri serta tingginya bea impor masuk di negara tujuan. Ketika penurunan volume ekspor, dunia usaha akan mengurangi produksinya karena hanya fokus untuk pemenuhan permintaan domestik dan pendapatan yang dihasilkan juga relatif sama karena ketika harga barang yang dijual mahal, maka akan menurun daya beli, ketika harga barang rendah pendapatan dunia usaha akan menurun.

Penelitian tentang pertumbuhan ekonomi dan faktor fundamental yang menentukan pertumbuhan ekonomi Indonesia perlu diteliti, hal ini disebabkan pertumbuhan ekonomi sebagai indikator pencapaian kinerja pemerintah dalam mensejahterakan masyarakat, dimana negara berkembangan seperti Indonesia sering mengalami permasalahan atas kenaikan harga barang (inflasi), pengeluaran atau belanja pemerintah yang kurang tepat sasaran bagi perkembangan ekonomi serta nilai ekspor yang kurang stabil akan menyebabkan perekonomian Indonesia rentan krisis.

Tingginya inflasi yangterjadi akan menghambat dalam pembangunan ekonomi dan aktifitasperekonomian pada masyarakat sehingga memperlambat kegiatan perekonomiandan pada akhirnya menurunkan pertumbuhan ekonomi.Pengaruh inflasi terhadap pertumbuhan ekonomi di Indonesia pernah diteliti oleh (Indriyani, 2016)menemukan bahwa inflasi berpengaruh signifikan terhadap pertumbuhan ekonomi di Indonesia tahun 2005-2015, sedangkan penelitian Ahmad (2017) menemukan bahwa inflasi tidak berpengaruh terhadap pertumbuhan ekonomi.

Hasil penelitian tentang pengeluaran pemerintah terhadap pertumbuhan ekonomi pernah 
diteliti oleh (Islamiah, 2015) yang menemukan bahwa pembangunan/modal berpengaruh negatif signifikan terhadap pertumbuhan ekonomi, artinya ketika pembelanjaan modal meningkat, maka pertumbuhan ekonomi cenderung menurun. Hal ini berbeda dengan penelitian yang dilakukan (Safari, 2016) yang menemukan bahwa pengeluaran pemerintah memiliki dampak positif terhadap pertumbuhan ekonomi.

Ekspor mempengaruhi pertumbuhan ekonomi Indonesia, hasil penelitian (Kristiawati, 2013) menemukan bahwa ekspor berpengaruh negatif dan signifikan terhadap pertubuhan ekonomi di Indonesia, jika volume ekspor ditingkatkan, maka pertumbuhan ekonomi akan melambat. Hal ini berbeda dengan penelitian yang dilakukan oleh Ginting yang menemukan bahwa ekspor berpengaruh positif signifikan trhadap pertumbuhan ekonomi.

Pengaruh Inflasi, Ekspor, Tenaga Kerja dan Nilai Tukar terhadap Pertumbuhan Ekonomi di Indonesia telah diteliti oleh (Kristiawati, 2013), (Larasati \& Sulastmiyati, 2018), dan (Dewi, 2013). Penelitian yang memberi fokus, Investasi, Inflasi, Tenaga Kerja, Pengeluaran Pemerintah dan Jumlah Penduduk terhadap Pertumbuhan Ekonomi telah ditileti oleh (Islamiah, 2015), (Safari, 2016), (Chtami, 2014), (Salhab \& Soedjono, 2012), dan (Lebang, Rotinsulu, \& Kawung, 2018). Sedangkan penelitian yang memberi fokus Ekspor, Pembentukan Modal dan Pengeluaran Pemerintah terhadap pertumbuhan Ekonomi Indonesia telah diteliti oleh (Safari, 2016).

Sejauh ini penelitian yang terkait dengan fokus yang peneliti lakukan masih sedikit dijumpai dalam publikasi, dapat dilihat pada penelitian penelitian terdahulu dan masih sedikit yang menggabungkan antara variabel inflasi, pengeluaran pemerintah dan ekspor terhadap pertumbuhan ekonomi. Oleh karenanya peneliti tertarik untuk melakukan penelitan.

Tujuan penelitian adalah untuk melihat pengaruh inflasi, pengeluaran pemerintah dan ekspor terhadap pertumbuhan ekonomi di Indonesia. Selanjutnya bagian kedua penelitian ini membahas tinjauan teoritis variabel-variabel terkait. Teknik analisis dipaparkan dibagian tiga, untuk melihat hasil dan pembahasan dijelaskan pada bagian keempat dan selanjutnya dibagian kelima merupakan bagian akhir penelitian akan memberikan kesimpulan dan saran.

\section{TINJAUAN TEORITIS}

\section{Pertumbuhan Ekonomi}

Pertumbuhan ekonomi merupakan suatu proses peningkatan kapasitas produktif dalam perekonomian secara terus menerus atau berkesinambungan sepanjang waktu sehingga menghasikan tingkat pendapatan dan output nasional yang semakin lama semakin besar(Antasari \& Soleh, 2012).

Pertumbuhan ekonomi merupakan suatu proses dalam perekonomian yang menyebabkan bertmbahnya barang dan jasa serta meningkatnya kemakmuran disuatu negara. Jadi apabila pertumbuhan ekonomi tinggi maka barang yang akan dihasilkan juga akan meningkat. Hal ini akan meningkatkan tingkat kesejahteraan masyarakat (Ardiansyah, 2017)..

Kesimpulan dari beberapa pendapat diatas pertumbuhan ekonomi yaitu proses meningkatnya produksi barang dan jasa dalam kegiatan ekonomi masyarakat sehingga menambahkan ouput atau Pendapatan Nasional meningkat sehingga pertumbuhan ekonomi dapat dicapai semaksimal mungkin.

Teori pertumbuhan ekonomi klasik memandang proses pembangunan ekonomi dari sisi penawaran. Namun teori pertumbuhan ekonomi Keynes menegaskan dari sisi permintaan yaitu permintaan efektif menentukan tingkat keseimbangan dan pendapatan nasional. Pengeluaran yang dilakukan oleh sektor rumah tangga, pengusaha, dan pemerintah serta sektor luar negeri dapat meningkatkan permintaan agregat dan pendapatan nasional(Jhingan, 2000).

\section{Inflasi}

Menurut Ardiansyah, (2017) inflasi adalah merupakan kejadian ekonomi yang sering terjadi meskipun kita tidak pernah menghendaki. Milton Friedman mengatakan inflasi ada dimana saja dan selalu merupakan fenomena moneter yang mencerminkan adanya pertumbuhan moneter yang berlebihan dan tidak stabil.

Menurut Ningsih, (2010) inflasi merupakankeadaan yang diakibatkan oleh tidak adanya keseimbangan antara permintaan akan barang dan persediannya, yaitu permintaan melebihi persediaan dan semakin besar perbedaan itu semakin besar bahaya yang ditimbulkan oleh inflasi bagi kesehatan ekonomi.

Berdasarkan penjelasan teori-teori diatas maka, dapat disimpulkan inflasi merupakan kenaikan harga barang dan jasa secara umun tidak pada satu barang tertentu dan terjadi terus-menerus selama suatu periode tertentu. 
Menurut Crismanto, (2007) tingginya tingkat inflasi akan membuat perekonomian suatu wilayah menjadi melemah. Karena kenaikan harga yang secara terus menerus membuat daya beli masyarakat melemah. Hal ini membuat perusahaan menurunkan jumlah produksinya dengan keadaan yang demikian akan membuat para investor menarik investnya, sehingga petumbuhan ekonomi ikut menurun. Jadi hubungan inflasi terhadap pertumbuhan ekonomi yaitu berkorelasi negatif.

Jika dibandingkan penelitian penulis dengan penelitian sebelumnya yaitu menurutKasidi \& Mwakanemela, (2011) meneliti tentang impact of inflation on economic growth: a case study of Tanzania, variabel yang digunakan dalam penelitan ini yaitu, inflasi dan pertumbuhan ekonomi, teknis analisis yang digunakan dalam penelitian ini yaitu, Koefisien korelasi dan teknik co-integrasi membentuk hubungan antarainflasi dan Pertumbuhan ekonomi dan Koefisien elastisitas diterapkan untuk mengukur tingkatresponsifnya perubahan pertumbuhan ekonomi terhadap perubahan tingkat harga umum, Hasil penelitain ini menunjukkan inflasi itumemiliki dampak negatif pada pertumbuhan ekonomi. Studi ini juga mengungkapkan bahwa tidak ada kointegrasi antara inflasi dan pertumbuhan ekonomi selama periode penelitian. Tidakdalam jangka panjanghubungan antara inflasi dan pertumbuhan ekonomi di Tanzania.

\section{Pengeluaran Pemerintah}

Pengeluaran pemerintah yaitu suatu tindakan pemerintah untuk mengatur jalannya perekonomian dengan cara menentukan besarnya penerimaan dan pengeluaran pemerintah setiap tahunnya, yang tercermin dalam dokumen APBN untuk nasional dan APBD untuk daerah atau regional(Sukirno, 2000)

Pengeluaran pemerintah mencerminkan kebijakan pemerintah. Apabila pemerintah telah menetapkan suatu kebijakan untuk membeli barang dan jasa, pengeluaran pemerintah mencerminkan biaya yang harus dikeluarkan oleh pemerintah untuk melaksanakan kebijakan tersebut(Mangkoesubroto, 2008).

Penengeluaran pemerintah adalah pembelian faktor-faktor produksi (input) dan pembelian produk (output). Menurut susanti dalam (Salhab \& Soedjono, 2012), peningkatan pengeluaran pemerintah sejalan dengan peningkatan kegiatan perekonomian suatu negara.
Dapat disimpulkan pengeluaran pemerintah adalah pengeluaran-pengeluaran Negara atau disebut juga belanja Negara. Belanja pembangunan adalah pengeluaran-pengeluaran pemerintah yang bersifat investasi, dan diajukan untuk melaksanakan tugas-tugas pemerintah sebagai salah satu pelaku pembangunan.

Menurut (Salhab \& Soedjono, 2012) peningkatan pengeluaran pemerintah sejalan dengan peningkatan kegiatan perekonomian suatu negara. Atau familiar disebut dengan hukum Wagner, yaitu pengeluaran pemerintah berhubungan secara positif dengan pertumbuhan ekonomi. Dimana jika pengeluran pemerintah meningkat maka akan menyebabkan pertumbuhan ekonomi juga meningkat.

Jika dibandingkan penelitian penulis dengan penelitian sebelumnya yaitu menurutDandan, (2011) meneliti tentang government expenditures and economic growth in jordan, variabel yang digunakan dalam penelitian ini yaitu, government expenditure and economic growth, teknis analisis yang digunakan adalah model regresi yang berbeda. Studi ini ditemukan bahwa pengeluaran pemerintah pada tingkat agregat telah dampak positif pada pertumbuhan PDB yang kompatibel dengan teori Keynesian, juga ditemukan minat pembayaran terbukti tidak memiliki pengaruh terhadap pertumbuhan PDB.

\section{Ekspor}

Ekspor merupakan total barang dan jasa yang dijual oleh sebuah negara ke negara lain, termasuk diantara barang-barang, asuransi, dan jasa-jasa pada suatu tahun tertentu secara legal (Purwanggono, 2015). Ekspor adalah kegiatan perdagangan yang memberikan rangsangan guna menumbuhkan permintaan dalam negeri yang menyebabkan timbulnya industri-industri pabrik besar, bersamaan dengan sruktur politik yang stabil dan lembaga sosial yang efisien(Todaro, 2006).

Ekspor akan memberikan efek yang positif ke dalam kegiatan ekonomi negara, kerena ia merupakan pengeluaran penduduk negara lain atas barang-barang yang dihasilkan dalam negeri. Pelaksaan pembayaran ekspor dilakukan dengan cara tunai kredit, yamg dapat dilaksanakan dengan cara: pembayaran dimuka (advance payment), Later of Credit $(L / C)$, Wesel inkaso (collecton draft) dengan kondisi against payment dan document against acceptance, perhitungan kemudian (open account), konsinyasi, dan pembayaran lain yang lazim dalam perdagangan luar negeri sesuai dengan kesepakatan antara penjual dan pembeli (Sukirno, 2013). 
Berdasarkan dari pengertian ekspor tersebut, bahwa kegiatan ekspor yang dilakukan oleh setiap Negara bertujan untuk meningkatkan pendapatan suatu negara, hal ini disebabkan karena kegiatan ekspor merupakan salah satu komponen pengeluaran agregat kerena ekspor sangat mempengaruhi tingkat pendapatan Nasional yang akan meningkatkan pertumbuhan ekonomi.

Menurut Adrian Sutawijaya, (2010) kenaikan ekspor akan memicu terjadinya gejolak pada pasar keuangan, nilai ekspor akan memporoleh valuta asing yang otomasi akan akan menghasilkan devisa sehingga dapat meningkatkan pertumbuhan ekonomi sehingga ekspor berpengaruh positif terhadap pertumbuhan ekonomi.

Jika dibandingkan penelitian penulis dengan penelitian sebelumnya yaitu menurut Seraphin \& Yinguo, (2015) meneliti tentang impact of export on economic growth in Madagascar, variabel yang digunakan dalam penelitian ini yaitu, ekspor dan pertumbuhan ekonomi, teknis analisis yang digunakan VAR dan IRF, hasil penelitian menunjukkan sebagian besar hubungan positif dan signifikan antara ekspor dan pertumbuhan, memperkenalkan hasil untuk variabel independen lainnya, seperti investasi dan populasi.

\section{Kerangka Konsptual}

Berdasarkan landasan teori dan kajian terhadap penelitian terdahulu, maka disusun suatu kerangka pemikiran teori mengenai penelitian yang akan dilakukan. Kerangka pemikiran teori dapat dilihat pada Gambar 1.

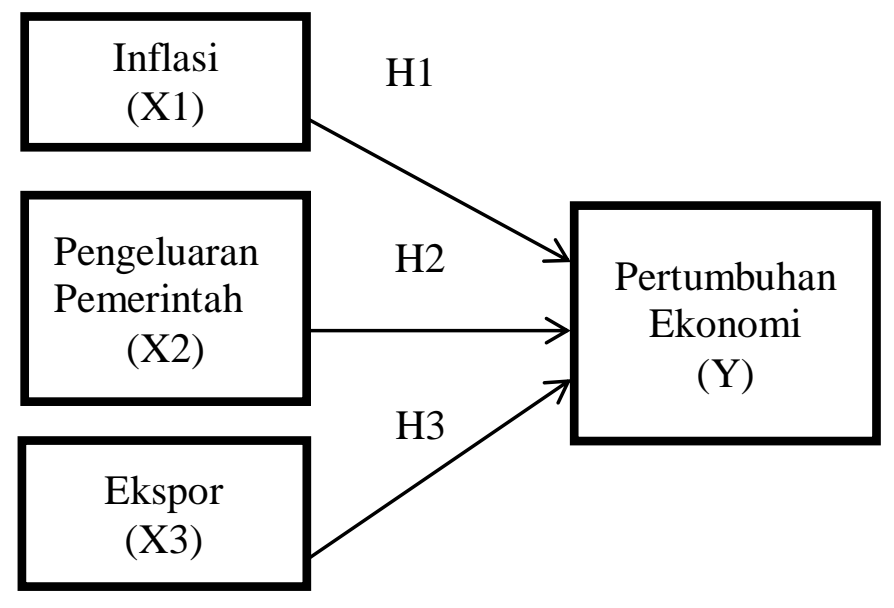

Gambar 1

Kerangka Konseptual

\section{Hipotesis}

H1 : Diduga tingkat Inflasi berpengaruh negatif dan signifikan terhadap pertumbuhan ekonomi di Indonesia.

$\mathrm{H} 2$ : Tingkat Pengeluaran Pemerintah berpangaruh posistif dan signifikan terhadap pertumbuhan ekonomi di Indonesia.

H3 : Diduga ekspor berpengaruh positif dan signifikan terhadap pertumbuhan ekonomi di Indonesia

\section{METODE PENELITIAN}

\section{Data dan Sumber Data}

Jenis data yang digunakan dalam penelitian ini adalah data kuantitatif. Yaitu data yang dapat diukur dalam skala numerik atau dalam bentuk angka. Dalam penelitian ini penulis menggunakan data sekunder dengan bentuk data time-series yaitu dalam bentuk tahunan dengan tahun pengamatan selama 27 tahun dari tahun 1990 sampai dengan tahun 2016.

\section{Operasioal Variabel}

Operasionalisasi variabel adalah sebagai petunjuk bagaimana variabel-variabel dalam penelitian diukur. Untuk mengatahui dan mempermudah pemahaman terhadap variabelvariabel yang akan dianalisis dalam penelitian ini, maka perlu dirumuskan operasionaliasasi variabel yaitu sebagai berikut:

1. Pertumbuhan Ekonomi (Y) adalah Suatu proses peningkatan produksi barang dan jasa dalam kegiatan ekonomi masyarakat, dengan menggunakan data dalam satuan persen.

2. Inflasi (X1) adalah kejadian apabila tingkat harga-harga dan biaya-biaya umum naik secara terus-menerus dalam jangka waktu yang panjang (dalam satuan presen).

3. Pengeluaran Pemerintah (X2) disebut juga belanja Negara. Belanja pembangunan adalah pengeluaran-pengeluaran pemerintah yang bersifat investasi, dan diajukan untuk melaksanakan tugas-tugas pemerintah sebagai salah satu pelaku pembangunan, dengan menggunakan data dalam satuan miliar rupiah.

4. Ekspor (X3) adalah Kegiatan menjual barang atau jasa ke negara lain dengan ketentuan yang berlaku secara legal. Kegiatan demikian itu akan meningkatkan pendapatan Nasional bagi negara dengan menggunakan data dalam satuan miliar rupiah. 


\section{Metode Analisis Vactor Autogeression model} (VAR)

Penelitian ini menggunakan model VAR. Model Vactor Autogeression model (VAR) merupakan salah satu metode time series yang digunakan dalam penelitian, terutama dalam bidang ekonomi. Model VAR ini dibangun dengan pertimbangan meminimalkan agar mampu menangkap fenomena ekonomi dengan baik. Dengan demikian VAR adalah model non struktur atau merupakan model tidak teoritis (ateoritis). Model VAR adalah model linier sehingga kita tidak perlu khawatir tentang bentuk model serta model VAR mudah diestimasi dengan menggunakan metode OLS (Widarjono, 2018).

$$
P E_{t}=\alpha+\sum_{i=1} \beta_{1} P E_{t-i}+\sum_{i=1} \beta_{2} \operatorname{Inf} f_{t-i}+\sum_{i=1} \beta_{3} P p_{t-i}+\sum_{i=1} \beta_{4} E k p_{t-i}+\varepsilon_{t 1}
$$

Keterangan :

$\mathrm{PE}$ :Pertumbuhan Ekonomi

Inf: Inflasi

PP: Pengeluaran Pemerintah

Ekp: Ekspor

$$
\begin{aligned}
& \varepsilon_{t 1}: \text { Faktor Gangguan } \\
& \beta_{1} \text { : Konstanta }
\end{aligned}
$$

Tahapan Uji Model VAR (Widarjono, 2017) adalah sebagai berikut:

\section{Uji Stasioner}

Uji stasioneritas/ uji akar-akar unit (Unit Root Test) dilakukan untuk menentukan stasioner tidaknya sebuah variabel. Data dikatakan stasioner apabila data tersebut mendekati rataratanya, dan apabila data yang diamati dalam uji derajat integrasi (Integration Test) sampai memperoleh data yang stasioner. Bentuk persaman uji stasioneritas dengan analisis ADF (Augemented Dickey Fuller)

\section{Penentuan Lag Optimal}

Tahap kedua di dalam analisis VAR adalah penentuan lag optimum. Penentuan jumlah lag dalam model VAR ditentukan pada kriteria informasi yang direkomendasikan oleh nilai terkecil dari Final Prediction Error (FPE), Akaike Information Criterion (AIC), Schwarz Criterion (SC), dan Hannan-Quinn (HQ). Program Eviews telah memberi petunjuk tanda bintang bagi lag yang ditetapkan sebagai lag optimum.

\section{Uji Kausalitas Granger}

Metode yang digunakan untuk menganalisis hubungan kausalitas antar variabel yang diamati adalah dengan uji kausalitas
Granger.Pengambilan keputusan dalam uji kausalitas dapat dilakukan dengan membandingkan nilai $t$-statistikhasil estimasi dengan nilai $t$-tabelatau dengan melihat nilai probabilitas $\mathrm{F}_{\text {-statistik. Jika nilai }}$ $\mathrm{t}$-statistikhasil estimasi lebih besar dari nilai $\mathrm{t}$-tabelatau nilai probabitas $\mathrm{F}$-statistik $<\dot{\alpha}=5 \%$, maka Hodi tolak artinya terdapat pengaruh antara dua variabel yang diuji, dan begitu juga sebaliknya.

\section{Uji Kointegrasi}

Uji kointegrasi untuk mengetahui apakah variabel bebas dan terikat terkointegrasi sehingga ada hubungan jangka panjang antar variabel. Dalam penelitian ini untuk melihat kointegrasi maka dilakukan melalui Johansen cointegrasi test. Apabila nilai trace statistic < critical value, begitu juga nilai max eign stat < critical value, ini berarti bahwa tidak terdapat kointegrasi di dalam model persamaan tersebut dan begitu pula sebaliknya.

\section{Uji Impulse Response}

IRF menunjukkan bagaimana respon dari setiap variabel endogen sepanjang waktu terhadap kejutan dari variabel itu sendiri dan variabel endogen lainnya.

\section{Uji Forecast Error Variance decomposition (FEVD)}

Uji ini dilakukan untuk memberi informasi mengenai bagaimana hubunngan dinamis antara variabel yang dianalisis.

\section{HASIL PENELITIAN DAN PEMBAHASAN}

\section{Perkembangan Pertumbuhan Ekonomi}

Pertumbuhan ekonomi merupakan suatu indikator penting untuk mengukur bagaimana keadaan pembangunan ekonomi suatu negara. Pertumbuhan ekonomi menunjukkan sejauh mana aktivitas perekonomian dalam menambah kesejahteraan masyarakat dengan bertambahnya pendapatan dalam satu periode tertentu adapun berdasarkan data yang diperoleh, pergerakan pertumbuhan ekonomi untuk peruode 1990 sampai 2016 dapat dilihat pada Gambar 2 sebagai berikut: 


\section{PE (\%)}

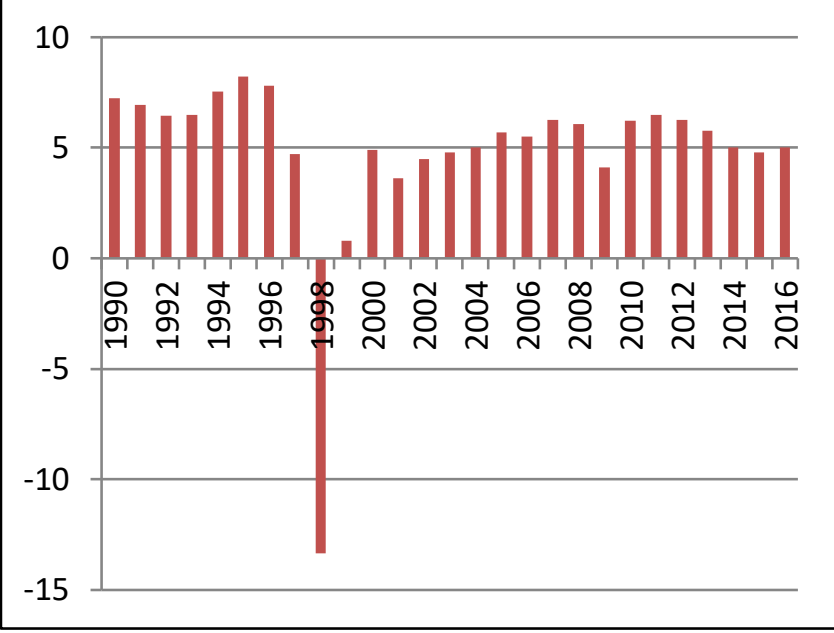

Sumber: Badan Pusat Statistik, (2019)

Gambar 2

\section{Perkembangan Pertumbuhan Ekonomi}

Pertumbuhan ekonomi dalam kurun waktu 10 tahun terakhir banyak mengalami fluktuasi dimana pada tahun 2006 pertumbuhan ekonomi mengalami penurunan dari tahun sebelumnya $6,28 \%$ menjadi $6,06 \%$ kemudian pertumbuhan ekonomi tertinggi ada pada tahun 2011 dengan pertumbuhan ekonomi sebesar 6,49\%. Setelah 2011, pertumbuhan ekonomi terus menurun sampai pada tahun 2015 sebesar 4,79\% yang kemudian pada tahun 2016 sebesar 5,02\%.

Pertumbuhan ekonomi Indonesia pada tahun 2015 menurun disebabkan dari konsumsi maupun sisi produksi. Dari sisi konsumsi menurunnya pasokan barang yang diakibatkan mundurnya masa panen. Sedangkan dari sisi produksi dikarenakan menurunnya produksi minyak mentah dan batu bara sehingga industri kilang minyak mengalami kontraksi. Pada tahun 2016 meningkat dari 4,79\% menjadi 5,02\% disebabkan oleh sektor konsumsi rumah tangga yang meningkat. Sektor rumah tangga berkontribusi untuk PDB sebesar 56,5\%.

\section{Perkembangan Inflasi}

Inflasi merupakan meningkatnya hargaharga secara umum secara terus menerus dalam satu periode tertentu. Kenaikan harga barang barang ini baru dikatakan sebagai inflasi jika bukan hanya satu atau dua harga barang lain ikut meningkat. Misalnya naiknya harga beras, harga bahan bakar, harga mobil, upah tenaga kerja, harga tanah, dan sewa barang-barang modal. Indonesia merupakan negara dengan suku yang beragam yang menyebabkan adanya berbagai kebudayaan. Muslim adalah penduduk mayoritas di Indonesia, dalam kebudayaan islam terdapat budaya puasa dan lebaran, sehingga dalam bulan puasa harga barang pokok dan kebutuhan lebaran cenderung meningkat daratis. Berdasarkan data yang diperoleh dapat dilihat pada gambar 3 sebagai berikut:

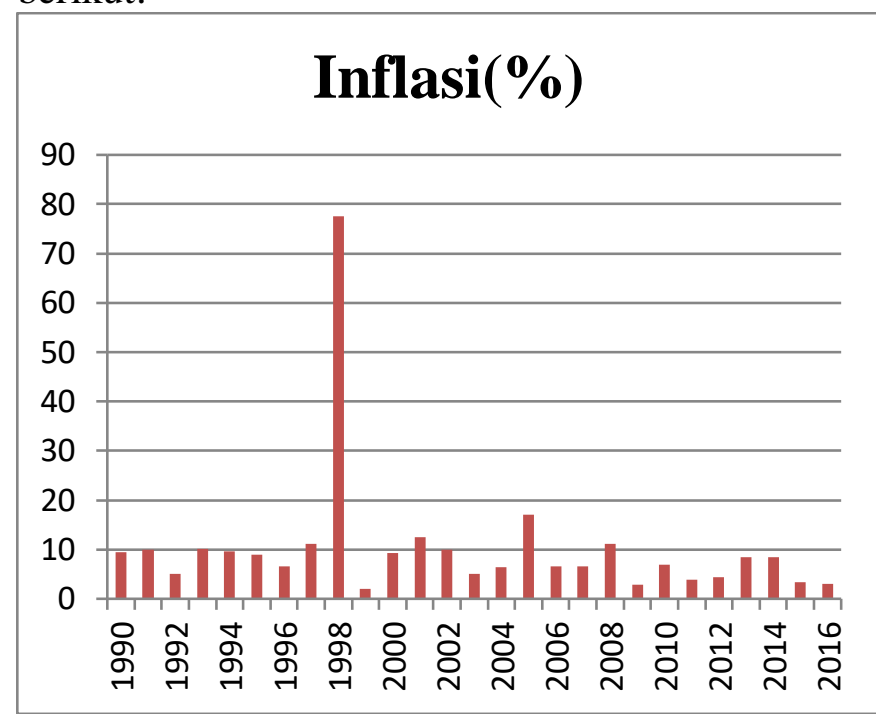

Sumber: Badan Pusat Statistik, (2019)

\section{Gambar 3}

Perkembangan Inflasi

Dari gambar diatas kita bisa melihat bahwa inflasi dalam kurun waktu 10 tahun terakhir terus mengalami fluktuasi dimana inflasi tertinggi berada pada tahun 2008 yaitu sebesar $11,06 \%$ yang diakibatkan oleh adanya krisis ekonomi global yang kemudian berdampak pada keadaan ekonomi Indonesia. Memburuknya perekonomian di negara Amerika membuat perekonimian negara-negara di Asia ikut melemah.

Inflasi terendah berada pada tahun 2009 sebesar 2,78\%. Kemudian pada tahun 2010 inflasi meningkat lagi dari tahun sebelumnya yaitu sebesar $6,96 \%$ disebabkan karena iklim Indonesia yang tidak menentu menyebabkan mundurnya masa panen dan juga naiknya harga komoditas internasional yang membuat harga-harga komoditas di Indonesia meningkat. Kemudian dalam 2 tahun inflasi menurun dan naik lagi pada tahun 2013 sebesar 8,38\% diakibatkan oleh harga BBM yang meningkat dan terus menurun hingga tahun 2016 sebesar 3,02\%.

\section{Perkembangan Pengeluaran Pemerintah di Indonesia}

Menurut Rostow dan Musgrave, perkembangan pengeluaran pemerintah sejalan dengan tahap perkembangan ekonomi dari suatu negara. Hal itu juga dialami oleh Indonesia dimana baik nilai nominal maupun rill dari total pengeluaran pemerintah terus meningkat sepanjang tahun. Berdasarkan dari data yang diperoleh dapat dilihat pada tabel 4. 


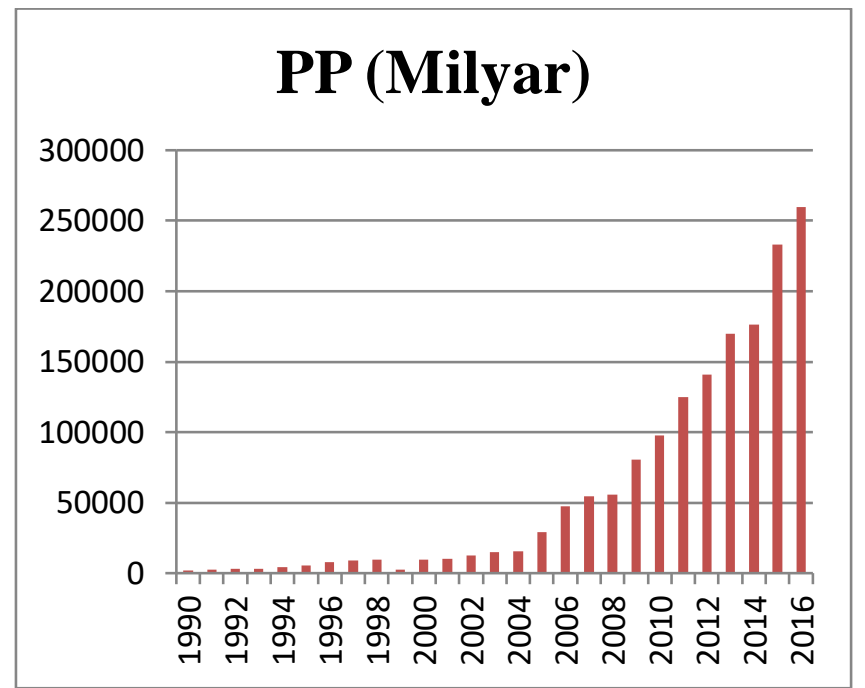

Sumber: Badan Pusat Statistik, (2019)

\section{Gambar 4}

\section{PerkembanganPengeluaran Pemerintah di Indonesia}

Berdasarkan Gambar 4 di atas bahwa pengeluaran pemerintah setiap tahunnya peningkatan, dimana pengeluaran pemerintah pada tahun 2008 yakni sebesar 55.963 milyar, peningkatan pengeluaran pemerintah khususnya barang modal tidak mampu mendongkrak pertumbuhan ekonomi, hal ini disebabkan barang modal yang dibelanjakan tidak berdampak secara langsung bagi perekonomian masyarkat dan merupakan aset yang kurang produktif.

Pengeluaran pemerintah semakin meningkat berada pada tahun 2014 sebesar 176.622 milyar. Kemudian pada tahun 2015 pengeluaran pemerintah meningkat lagi dari tahun sebelumnya yaitu sebesar 233.281 milyar dimana sebagian besar barang modal sebelumnya dan yang baru dialihkan untuk peningkatan produksi Badan Usaha Milik Negara (BUMN) dan Badan Usaha Milik Daerah (BUMD), hingga secara langsung terjadi peningkatan poduksi dalam negeri dan pendapatan masyarakatsebagai pekerja maupun sebagai produsen untuk kebutuhan barang dalam negeri.

\section{Perkembangan Ekspor}

Ekspor merupakan kegiatan penting dalam perdagangan internasional, dimana ekspor adalah kegiatan menjual barang ke luar negeri dengan menggunakan pembayaran, kualitas kuantitas dan syarat penjualan lainnya yang telah disetujui antara eksportin dan importir. Agar mampu mengekspor, suatu negara harus mampu menghasilkan barang dan jasa yang mampu bersaing di pasar internasional. Berdasarkan data yang diperoleh, maka pergerakan Ekspor untuk periode 1990 sampai 2016 dapat dilihat pada gambar 5 adalah sebagai berikut

\section{Ekspor (Juta USD)}

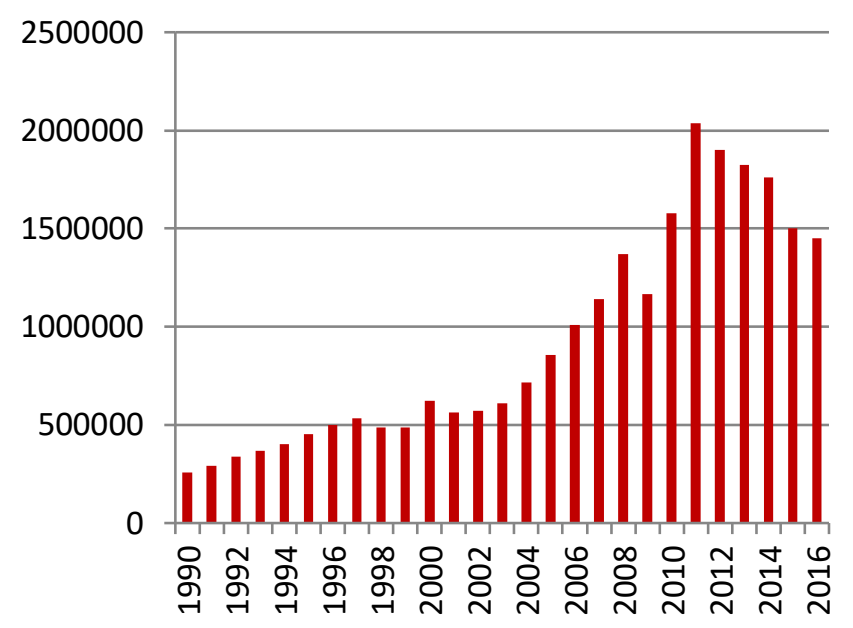

Sumber: Badan Pusat Statistik, (2019)

\section{Gambar 5}

Perkembangan Nilai Tukar Rupiah

Bersadarkan Gambar 5 di atas ekspor di Indonesia mengalami fluktuasi dari terendah sampai tertinggi, pada periode 2012- 2016 menunjukkan kontribusi yang semakin menurun. Dimana pada tahun 2011 nilai ekspor mengalami peningkatan begitu pesat yakni sebesar 203.496.6 juta US\$, kemudian mengalami penurunan hingga tahun 2016 yaitu sebesar 145.186.2 juta US\$.

Terjadinya penurunan nilai ekspor pada tahun 2016 disebabkan oleh permintaan barang dan jasa dari luar negeri mengalami penurunan, serta larangan eskpor bagi beberapa komoditi tertentu yang belum mampu mencukupi kebutuhan dalam negeri serta tingginya bea impor masuk di negara tujuan. Ketika penurunan volume ekspor, dunia usaha akan mengurangi produksinya karena hanya fokus untuk pemenuhan permintaan domestik dan pendapatan yang dihasilkan juga relatif sama karena ketika harga barang yang dijual mahal, maka akan menurun daya beli, ketika harga barang rendah pendapatan dunia usaha akan menurun.

\section{Hasil Penelitian}

\section{Uji Stasioneritas/Akar (Unit Root Test)}

Berikut ini tabel 2 yaitu uji unit root dengan augmented dickey fuller $(A D F)$ :

\section{Tabel 2}

\section{Uji Unit Root Test dengan Augmented Dickey Fuller (ADF)}

\begin{tabular}{|c|c|c|c|c|c|}
\hline $\begin{array}{c}\text { Var } \\
\text { iabe } \\
1\end{array}$ & $\begin{array}{c}\text { Unit } \\
\text { Root }\end{array}$ & $\begin{array}{c}\text { ADF test } \\
\text { Satistic }\end{array}$ & $\begin{array}{c}\text { Critical } \\
\text { Value } \\
5 \%\end{array}$ & $\begin{array}{c}\text { Prob } \\
\text { ADF }\end{array}$ & $\begin{array}{c}\text { Keterang } \\
\text { an }\end{array}$ \\
\hline PE & Level & $\begin{array}{c}- \\
3.581472\end{array}$ & $\begin{array}{c}- \\
3.5950\end{array}$ & 0.0514 & Stasioner \\
\hline
\end{tabular}




\begin{tabular}{|c|c|c|c|c|c|}
\hline & & & 26 & & \\
\hline & $\begin{array}{l}\text { First } \\
\text { Diff }\end{array}$ & $\begin{array}{c}- \\
6.131872\end{array}$ & $\begin{array}{c}- \\
3.6032 \\
02\end{array}$ & 0.0002 & Stasioner \\
\hline & $\begin{array}{l}\text { Secon } \\
\text { d Diff }\end{array}$ & $\begin{array}{c}- \\
7.552396\end{array}$ & $\begin{array}{c}3.6908 \\
14\end{array}$ & 0.0001 & Stasioner \\
\hline & Level & 5.409985 & $\begin{array}{c}- \\
3.5950 \\
26\end{array}$ & 0.0009 & Stasioner \\
\hline $\begin{array}{c}\text { Inla } \\
\text { si }\end{array}$ & $\begin{array}{l}\text { First } \\
\text { Diff }\end{array}$ & 6.031873 & $\begin{array}{c}- \\
3.6121 \\
99\end{array}$ & 0.0003 & Stasioner \\
\hline & $\begin{array}{l}\text { Secon } \\
\text { d Diff }\end{array}$ & $\begin{array}{c}- \\
6.055618\end{array}$ & $\begin{array}{c}3.6908 \\
14\end{array}$ & 0.0006 & Stasioner \\
\hline & Level & 0.071832 & $\begin{array}{c}- \\
3.6584 \\
46\end{array}$ & 0.9943 & Tidak \\
\hline PP & $\begin{array}{l}\text { First } \\
\text { Diff }\end{array}$ & $\begin{array}{c}- \\
0.817795\end{array}$ & $\begin{array}{c}3.6584 \\
46 \\
\end{array}$ & 0.9465 & Tidak \\
\hline & $\begin{array}{l}\text { Secon } \\
\text { d Diff }\end{array}$ & $\begin{array}{c}- \\
6.514733\end{array}$ & $\begin{array}{c}- \\
3.6584 \\
46 \\
\end{array}$ & 0.0002 & Stasioner \\
\hline $\begin{array}{l}\text { Eks } \\
\text { por }\end{array}$ & $\begin{array}{l}\text { Level } \\
\text { First } \\
\text { Diff } \\
\text { Secon } \\
\text { d Diff }\end{array}$ & $\begin{array}{c}- \\
1.612736 \\
- \\
4.139398 \\
- \\
6.845457\end{array}$ & $\begin{array}{c}- \\
3.5950 \\
26 \\
- \\
3.6032 \\
02 \\
- \\
3.6220 \\
33\end{array}$ & $\begin{array}{l}0.7599 \\
0.0166 \\
0.0001\end{array}$ & $\begin{array}{l}\text { Tidak } \\
\text { Stasioner } \\
\text { Stasioner }\end{array}$ \\
\hline
\end{tabular}

Sumber: Hasil Pengolahan Data, 2019

Berdasarkan tabel 2 dapat dijelaskan bahwa hasil uji unit root pada tingkat signifikansi 5 persen, variabel PE, INFLASI, PP dan EKSPOR stasioner pada secon difference. Karena variabel PE, INFLASI, PP dan EKSPOR memiliki probabilitas lebih kecil dari tingkat pengujian alpha 5 persen. Dengan demikian variabel PE, INFLASI, PP dan EKSPOR stasioner pada tingkat secon difference.

\section{Penentuan lag Optimal}

\section{Tabel 3}

\section{Panjang Lag Length Berdasarkan} Beberapa Kriteria

\begin{tabular}{ccccccc} 
Lag & LogL & LR & FPE & AIC & SC & HQ \\
\hline \hline & & & & & \multicolumn{3}{c}{65.968} & 65.828 \\
0 & -818.1739 & NA & $4.32 \mathrm{e}+23$ & 65.77391 & 93 & 00 \\
& & & & & 61.13 & 60.43 \\
1 & -732.0123 & $137.8586^{*}$ & $1.61 \mathrm{e}+21^{*}$ & $60.16098^{*}$ & $608^{*}$ & $143^{*}$ \\
2 & -721.6453 & 13.26976 & $2.83 \mathrm{e}+21$ & 60.61162 & 80 & 44 \\
\hline \hline
\end{tabular}

Sumber: Hasil Pengolahan Data, 2019

Berdasarkan Tabel 3 kriteria dari (LR) Sequential Modifie LRtest statistic, FPE (Final
Prediction Error), Akaike Information Creterion (AIC), (SC) Schwarz information criterion dan Hannan-Quin Information Creterion (HQ) terletak pada lag 1. Dengan demikian dalam penelitian ini panjang lag optimal yang akan dipakai adalah 1 . Setelah diakumulasikan maka jumlah bintang terbanyak terletak pada lag 1 .

\section{Uji Kointegrasi ( Cointegration Test)}

Berikut ini hasil uji kointegritasi dengan metode johansen dapat dilihat pada tabel 4 yaitu:

\section{Tabel 4}

Hasil Uji Kointegrasi

\begin{tabular}{|c|c|c|c|c|}
\hline $\begin{array}{l}\text { Hypothesi } \\
\text { zed } \\
\text { No. of } \\
\text { CE(s) }\end{array}$ & Eigenvalue & $\begin{array}{c}\text { Trace } \\
\text { Statistic }\end{array}$ & $\begin{array}{l}0.05 \\
\text { Critical Value }\end{array}$ & Prob. ${ }^{* \star}$ \\
\hline None * & 0.908548 & 92.11338 & 63.87610 & 0.0000 \\
\hline At most 1 & 0.508545 & 34.70680 & 42.91525 & 0.2573 \\
\hline At most 2 & 0.399473 & 17.65758 & 25.87211 & 0.3674 \\
\hline At most 3 & 0.202110 & 5.418824 & 12.51798 & 0.5374 \\
\hline
\end{tabular}

\begin{tabular}{ccccc}
\hline \hline $\begin{array}{c}\text { Hypothesi } \\
\text { zed } \\
\text { No. of } \\
\text { CE(s) }\end{array}$ & Eigenvalue & $\begin{array}{c}\text { Max- } \\
\text { Eigen }\end{array}$ & 0.05 & \\
\hline \hline None $^{*}$ & 0.908548 & 57.40657 & 32.11832 & 0.0000 \\
At most 1 & 0.508545 & 17.04922 & 25.82321 & 0.4536 \\
At most 2 & 0.399473 & 12.23876 & 19.38704 & 0.3933 \\
At most 3 & 0.202110 & 5.418824 & 12.51798 & 0.5374
\end{tabular}

Sumber: Hasil Pengolahan Data, 2019

Berdasarkan tabel 4 di atas diperoleh hasil pengujian kointegrasi dengan menggunakan metode johansen yaitu nilai trece statistic dan max-eigenstatistic pada $\mathrm{r}=0$ lebih kecil dari critical value. Hal ini berarti tidak adanya kointegrasi. Berdasarkan hasil di atas dapat dilihat bahwa diantara keempat variabel dalam penelitian ini tidak terdapat kointegrasi. Dengan demikian dari hasil uji kointegrasi tersebut mengidentifikasi bahwa variabel PE, INFLASI, PP dan EKSPOR tidak memiliki hubungan stabilias/keseimbangan dan kesamaan pergerakan dalam jangka panjang.

\subsubsection{Pengujian Stabilitas VAR Tabel 5 VAR Stability Condition Check}

\begin{tabular}{cc} 
Root & Modulus \\
\hline \hline 1.108346 & 1.108346 \\
0.990736 & 0.990736 \\
-0.865923 & 0.865923 \\
$0.178354-0.466900 \mathrm{i}$ & 0.499806
\end{tabular}




$\begin{array}{ll}0.178354+0.466900 \mathrm{i} & 0.499806 \\ -0.341666 & 0.341666 \\ 0.251018 & 0.251018 \\ -0.025274 & 0.025274\end{array}$

Inverse Roots of AR Characteristic Polynomial

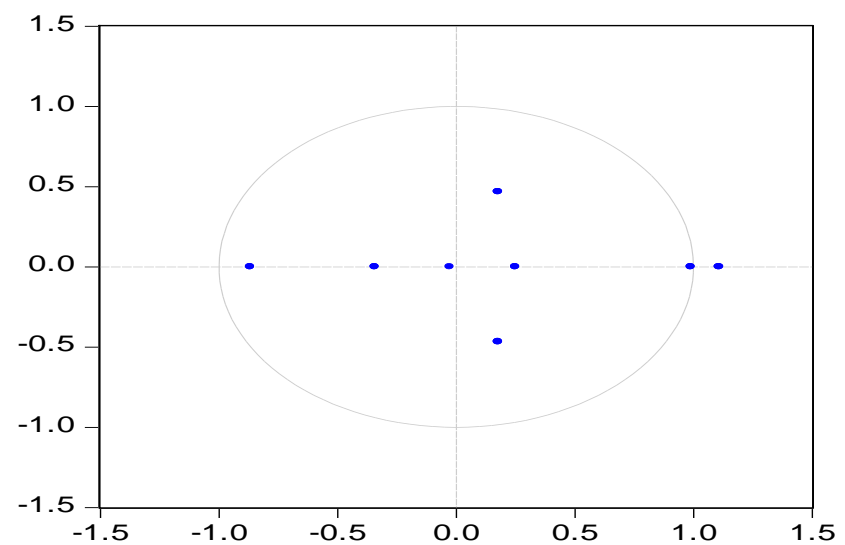

Sumber: Hasil Pengolahan Data, 2019

Keterangan: No root lies outside the unit circle.

VAR satisfies the stabilitycondition.

Berdasarkan hasil pengujian stabilitas

Vector Autoregression pada table 4.4 menunjukkan bahwa persamaan VAR memiliki nilai modulus kurang dari satu pada lag 1 sehingga dapat disimpulkan bahwa model VAR yang dibentuk tidak stabil karena nilai modulus lebih besar dari 1. Pada Graph dapat dilihat bahwa titik invers roots of $\mathrm{AR}$ polynominal hanya satu yang berada di luar lingkaran.

\section{Uji Kausalitas Granger}

\section{Tabel 6}

\section{Granger Causality Test Lag 1}

\begin{tabular}{|c|c|c|c|c|c|c|c|c|}
\hline \multirow{5}{*}{$\begin{array}{l}\text { Null Hypothesis: } \\
\text { DDINFLASI does not Granger Cause } \\
\text { DDPE } \\
\text { DDPE does not Granger Cause } \\
\text { DDINFLASI }\end{array}$} & \multirow{5}{*}{ Obs } & F-Statistic & Prob. & \multirow{2}{*}{\multicolumn{5}{|c|}{$\begin{array}{l}\text { dari } 0,05 \text { yaitu } 0.8665 \text { berarti terima hipotesis nol } \\
\text { apat disimpulkan tidak terjadi kausalitas apapur } \\
\text { antar kedua variabel PE dan EKS. }\end{array}$}} \\
\hline & & \multirow{3}{*}{0.01928} & \multirow{3}{*}{0.8908} & & & & & \\
\hline & & & & & & & & \\
\hline & & & & \multirow{2}{*}{\multicolumn{5}{|c|}{ Analisis Vector Autoregression Estimates }} \\
\hline & & 0.01563 & 0.9016 & & & & & ites \\
\hline \multirow{3}{*}{$\begin{array}{l}\text { DDPP does not Granger Cause } \\
\text { DDPE } \\
\text { DDPE does not Granger Cause } \\
\text { DDPP }\end{array}$} & \multirow{3}{*}{25} & \multirow{2}{*}{0.12297} & \multirow{2}{*}{0.7292} & \multicolumn{5}{|c|}{ Estimasi VAR } \\
\hline & & & & & DDPE & DDINFLASI & DDPP & DDEKSPOR \\
\hline & & 0.61331 & 0.4419 & & O 355470 & - 3690 ח & -8187474 & -1697949 \\
\hline DDEKSPOR does not Granger Cause & \multirow{4}{*}{25} & & & \multirow[b]{3}{*}{ DDINFLASI } & $(0.45257)$ & $(1.62812)$ & $(1038.22)$ & $(17497.0)$ \\
\hline DDPE & & 0.07421 & 0.7878 & & {$[0.78545]$} & {$[-0.22664]$} & {$[-0.07886]$} & {$[-0.97042]$} \\
\hline \multirow{2}{*}{$\begin{array}{l}\text { DDPE does not Granger Cause } \\
\text { DDEKSPOR }\end{array}$} & & & & & & & & \\
\hline & & 0.02894 & 0.8665 & $(-1)$ & 0.022851 & -0.221898 & -145.2794 & -6028.656 \\
\hline \multirow{4}{*}{$\begin{array}{l}\text { DDPP does not Granger Cause } \\
\text { DDINFLASI } \\
\text { DDINFLASI does not Granger Cause } \\
\text { DDPP }\end{array}$} & \multirow{4}{*}{25} & & & \multirow{4}{*}{$\operatorname{DDPP}(-1)$} & [0.17392] & {$[-0.46947]$} & {$[-0.48201]$} & {$[-1.18686]$} \\
\hline & & 1.15755 & 0.2936 & & & & & \\
\hline & & & & & 1.33E-05 & $-2.97 \mathrm{E}-05$ & 1.149093 & -1.603979 \\
\hline & & 0.89780 & 0.3537 & & $(4.9 \mathrm{E}-05)$ & $(0.00018)$ & $(0.11299)$ & (1.90428) \\
\hline \multirow{4}{*}{$\begin{array}{l}\text { DDEKSPOR does not Granger Cause } \\
\text { DDINFLASI } \\
\text { DDINFLASI does not Granger Cause } \\
\text { DDEKSPOR }\end{array}$} & & & & \multirow{4}{*}{$\begin{array}{c}\text { DDEKSPOR( } \\
-1)\end{array}$} & [ 0.26909] & {$[-0.16758]$} & [ 10.1695] & {$[-0.84230]$} \\
\hline & 25 & 1.15372 & 0.2944 & & & & & \\
\hline & & & & & $-7.90 \mathrm{E}-07$ & $-3.16 \mathrm{E}-06$ & 0.003169 & 1.092388 \\
\hline & & 0.53408 & 0.4726 & & $(4.9 \mathrm{E}-06)$ & $(1.8 \mathrm{E}-05)$ & $(0.01125)$ & $(0.18967)$ \\
\hline
\end{tabular}

DDEKSPOR does not Granger Cause

DDPP

DDPP does not Granger Cause

Sumber: Hasil Pengolahan Data, 2019

Berdasarkan tabel 6 diatas, variabel pertumbuhan ekonomi (PE) secara statistik tidak signifikan mempengaruhi nilai inflasi (INF) dengan nilai prob lebih besar dari 0,05 yaitu 0.8908 berarti terima hipotesis nol dan variabel pertumbuhan ekonomi (PE) secara statistik tidak signifikan mempengaruhi variabel pertumbuhan ekonomi (PE) yang dibuktikan dengan nilai prob masing-masing variabel lebih besar dari 0,05 yaitu 0.9016 sehingga dapat disimpulkan tidak terjadi kausalitas searah antara kedua variabel PE dan INFLASI. Kemudian yang kedua variabel pertumbuhan ekonomi (PE) secara statistik tidak signifikan mempengaruhi variabel pengeluaran pemerintah (PP) dan begitu pula sebaliknya variabel PP secara statistik tidak mempengaruhi variabel pertumbuhan ekonomi (PE) yang dibuktikan nilai probabilitas masing-masing variabel lebih besar dari 0,05 yaitu 0.7292 dan 0.4419 (hasil keduanya adalah terima hipotesis nol) sehingga disimpulkan tidak terjadi kaulitas apapun untuk kedua variabel PE dan PP. Selanjutnya yang ketiga, variabel pertumbuhan ekonomi (PE) secara statistik tidak signifikan mempengaruhi nilai ekspor (EKS) dengan nilai prob lebih besar dari 0,05 yaitu 0.7878 berarti terima hipotesis nol dan variabel nilai ekspor (EKS) secara statistik tidak signifikan mempengaruhi variabel pertumbuhan ekonomi (PE) yang dibuktikan dengan nilai prob variabel lebih besar dari 0,05 yaitu 0.8665 berarti terima hipotesis nol. apat disimpulkan tidak terjadi kausalitas apapun

.


$[-0.16093] \quad[-0.17880] \quad[0.28161] \quad[5.75949]$

$\begin{array}{lllll}\text { C } & 2.943133 & 18.80817 & 1967.343 & 187730.0\end{array}$

$\begin{array}{llll}(4.55050) & (16.3704) & (10439.2) & (175930 .)\end{array}$

$\left[\begin{array}{lllll}{[0.64677]} & {[1.14891]} & {[0.18846]} & {[1.06707]}\end{array}\right.$

Sumber: Hasil Pengolahan Data, 2019

Berdasarkan tabel diatas 7 dengan t-tabel 1.71387 maka variabel PE berpengaruh positif tidak signifikan terhadap dirinya sendiri dimana nilai $\mathrm{t}$ statistik lebih kecil dari nilai $\mathrm{t}$ tabel yaitu sebesar 0.78545 lebih kecil dari t table yaitu sebesar 1.71387 . Variabel INFLASI berpengaruh positif tidak signifikan terhadap PE. Variabel PP berpengaruh positif tidak signifikan terhadap PE. Ekspor berpengaruh negatif dan tidak signifikan terhadap PE karena nilai $\mathrm{t}$ satistik lebih kecil dari nilai t table yaitu sebesar 0.16093 lebih kecil dari t table yaitu sebesar 1.71387 .

\section{Analisis Impulse Response}
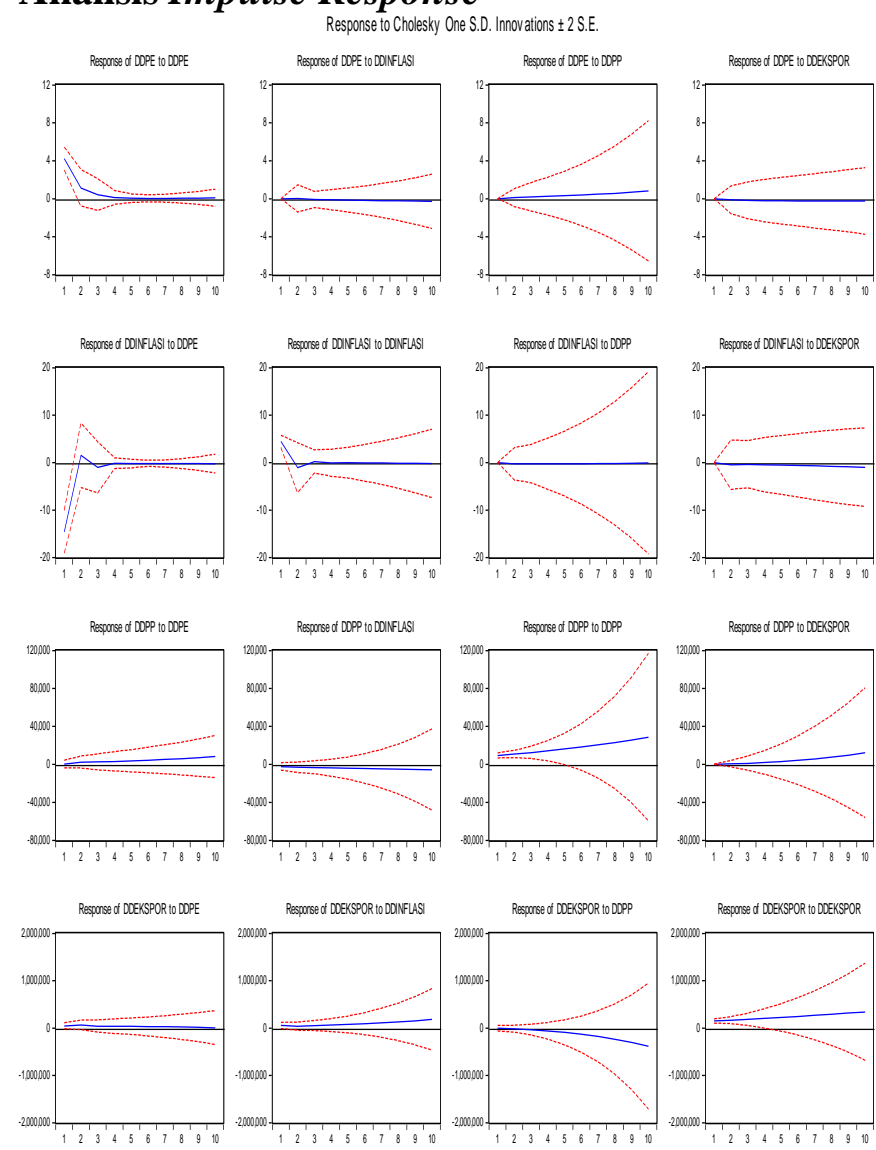

Sumber: Hasil Pengolahan Data, 2019

\section{Gambar 6 \\ Impulse Response Fungction}

Pada awal periode yaitu tahun pertama sampai tahun ketiga respon pertumbuhan ekonomi sangat fluktuaktif. Sejak terjadinya shock atau goncangan terhadap variabel inflasi dari tahun pertama sampai tahun ketiga menurun signifikan dan negatif serta tahun keempat mencapai titik kesimbangan atau equilibriumnya. Artinya butuh waktu empat tahun agar pertumbuhan ekonomi mengalami kestabilan setelah terjadi shock pada inflasi.

Respon pengeluaran pemerintah terhadap Pertumbuhan ekonomi pada awal periode mengalami fluktuasi positif sampai tahun keempat dan mencapai titik keseimbangan pada tahun kelima. Kemudian respon pengeluaran pemerintah mengalami fluktuasi dari tahun keempat mengalami peningkatan sampai pada tahun kedelapan serta positif dari tahun kelima sampai tahun ke kesepuluh terhadap variabel itu sendiri. Artinya butuh waktu enam tahun agar pengeluaran pemerintah kembali stabil.

Respon ekspor terhadap pertumbuhan ekonomi pada awal periode mengalami fluktuasi sampai tahun kedelapan dan mencapai titik keseimbangan pada tahun kesembilan. Kemudian respon ekspor mengalami fluktuasi dari tahun pertama mengalami peningkatan hingga pada tahun ketiga serta positif dari tahun keempat sampai tahun ke sepuluh terhadap variabel itu sendiri. Artinya butuh waktu delapan tahun agar ekspor agar kembali stabil.

\section{Analisis Variance Decomposition Tabel 8} Variance Decomposition

\begin{tabular}{cccccc} 
Period & S.E. & DDPE & DDINFLASI & DDPP & DDEKSPOR \\
\hline \hline 1 & 4.246725 & 100.0000 & 0.000000 & 0.000000 & 0.000000 \\
2 & 4.401665 & 99.84158 & 0.004412 & 0.083233 & 0.070771 \\
3 & 4.430289 & 99.45628 & 0.040529 & 0.279077 & 0.224118 \\
4 & 4.445439 & 98.86317 & 0.100005 & 0.614980 & 0.421848 \\
5 & 4.464739 & 98.02532 & 0.192848 & 1.133747 & 0.648087 \\
6 & 4.490999 & 96.88881 & 0.318772 & 1.901587 & 0.890826 \\
7 & 4.526790 & 95.37116 & 0.484765 & 3.005344 & 1.138733 \\
8 & 4.575333 & 93.37321 & 0.697782 & 4.551377 & 1.377629 \\
9 & 4.640798 & 90.78487 & 0.964685 & 6.660452 & 1.589991 \\
10 & 4.728460 & 87.49723 & 1.290108 & 9.456806 & 1.755854
\end{tabular}

Sumber : Hasil Pengolahan Data, 2019

\section{Berdasarkan}

pengujian

variance decomposition diatas, periode pertama 100 persen variabilitas PE dijelaskan oleh variabel itu sendiri, sementara dari INFLASI, PP dan EKSPOR dalah 0 persen. Begitu juga dengan variabel INFLASI, PP dan EKSPOR 100 persen dijelaskan oleh variabel itu sendiri, sementara dari PE adalah 0 persen. Pada periode kedua, variabilitas PE dijelaskan oleh ratarata PE itu sendiri sebesar 99.84persen, sementara dari variabel INFLASI sebesar 0.004persen, sementara dari variabel PP sebesar 0.083 persen dan variabel EKSPOR sebesar 0.070persen. Pada periode ketiga variabilitas $\mathrm{PE}$ dijelaskan oleh ratarata variabel PE itu sendiri sebesar 99.45persen, 
sementara variabel INFLASI sebesar 0.040 persen.

Sementara variabel PP sebesar 0.279dan variabel EKSPOR sebesar 0.224persen. Kemudian pada periode keempat variabilitas PE dijelaskan oleh rata-rata PE itu sendiri adalah sebesar 98.86 persen, sementara dijelaskan oleh variabel INFLASI sebesar 0.100005 persen, sementara variabel PP sebesar 0.614 dan variabel EKSPOR sebesar 0.421 persen. Kemudian pada periode kelima variabilitas PE dijelaskan oleh rata-rata $\mathrm{PE}$ itu sendiri adalah sebesar 98.02 persen, sementara dijelaskan oleh variabel INFLASI sebesar 0.19 persen, sementara variabel PP sebesar 1.13 persen dan variabel EKSPOR sebesar 0.64 persen. Lanjut pada periode keenam variabilitas PE dijelaskan oleh rata-rata $\mathrm{PE}$ itu sendiri adalah sebesar 96.88 persen, sementara dari variabel INFLASI sebesar 0.31 persen, sementara variabel PP sebesar 1.90 dan variabel EKSPO adalah sebesar 0.89 persen. Pada periode berikutnya sampai dengan periode 10 variabilitas $P E$ dijelaskan oleh rata-rata $P E$ itu sendiri semakin mengecil yaitu sebesar 87.49 persen. Sampai periode 10 PE dijelaskan oleh variabel itu sendiri semakin mengecil, sementara dari variabel INFLASI, PP dan EKSPOR semakin meningkat. Dari penjelasan tersebut dapat disimpulkan bahwa inflasi, pengeluaran pemerintah dan ekspor memberikan kontribusi yang besar terhadap pertumbuhan ekonomi.

\section{Pembahasan \\ Hubungan Inflasi terhadap Pertumbuhan Ekonomi}

Berdasarkan hasil pengujian yang telah dilakukan dapat disimpulkan bahwa inflasi memilki hubungan positif dan tidak signifikan terhadap pertubuhan ekonomi. Hasil penelitian ini sejalan dengan penelitian yang dilakukan oleh (Kalsum, 2017), dimana variabel inflasi tidak berpengaruh signifikan terhadap pertumbuhan ekonomi di Sumatera Utara selama periode 2011-2015.

\section{Hubungan Pengeluaran Pemerintah Terhadap Pertumbuhan Ekonomi}

Berdasarkan hasil pengujian yang telah dilakukan dapat disimpulkan bahwa pengeluaran pemerintah berpengaruh positif dan tidak signifikan terhadap pertumbuhan ekonomi. Penelitian ini didukung pula oleh penelitian yang dilakukan oleh Raharjo, (2006) dengan judul penelitian Pengaruh Pengeluaran Pemerintah dan Investasi Swasta dan Angkatan Kerja Terhadap
Pertumbuhan Ekonomi Tahun 1982-2003 Kota Semarang. dimana variabel pengeluaran pemerintah (pembangunan) pengaruh positif dan tidak signifikan terhadap pertumbuhan ekonomi Kota Semarang. Begitu juga hasil penelitian Merri Anitasari dan Anitasari \& Soleh, (2012), dengan judul Pengaruh Pengeluaran Pemerintah Terhadap Pertumbuhan Ekonomi Provinsi Bengkelu, bahwa variabel Pengeluaran Pemerintah berpengaruh positif namun tidak siginfikan terhadap Pertumbuhan Ekonomi di Provinsi Bengkelu.

\section{Hubungan Ekspor Terhadap Pertumbuhan Ekonomi}

Berdasarkan hasil pengujian yang telah dilakukan dapat disimpulkan bahwa ekspor berpengaruh negatif dan tidak signifikan terhadap pertumbuhan ekonomi. Penelitian ini sejalan dengan penelitian yang dilakukanAnggraeni, (2011) dengan judul penelitian pengaruh ekspor, impor dan investasi terhadap pertumbuhan ekonomi di kepulauan riau tahun 2009-2016 Variabel ekspor secara parsial tidak memiliki pengaruh secara signifikan terhadap pertumbuhan ekonomi Kepulaua Riau. Begitu juga dengan penelitian Pridayanti, (2012)yang berjudul pengaruh ekspor, impor dan nilai tukar terhadap pertumnuhan ekonomi indonesia. Dimana variabel ekspor berpengaruh negatif terhadap pertumbuhan ekonomi di Indonesia.

\section{KESIMPULAN DAN SARAN Kesimpulan}

Berdasarkan hasil penelitian yang telah dilakukan maka dapat disimpulkan beberapa kesimpulan diantaranya adalah sebagai berikut:

1. Inflasi memiliki korelasi positif dan tidak signifikan terhadap Pertumbuhan Ekonomi. Hal ini dapat dilihat dari pengujian Vector Auto Regression (VAR) yang menunjukkan bahwa t-hitung inflasi sebesar 0.78545 lebih kecil dari t-tabel penelitian sebesar 1.71387. Artinya jika pertumbuhan ekonomi meningkat sebesar $1 \%$ maka inflasi Indonesia meningkat sebesar 0.78545 persen.

2. Pengeluarn Pemerintah memiliki korelasi positif dan tidak signifikan terhadap pertumbuhan ekonomi Indonesia selama priode penelitian. Hal ini dapat dilihat dari pengujian Vector Autoregression (VAR) dimana t-hitung inflasi sebesar 0.17392 lebih kecil dari t-tabel sebesar 1.71387. Artinya jika pertumbuhan ekonomi meningkat sebesar $1 \%$ maka pengeluaran 
pemerintah meningkat sebesar 0.17392 milyar.

3. Ekspor memiliki korelasi negatif dan tidak signifikan terhadap pertumbuhan ekonomi, hal ini dapat dilihat dari pengujian Vecto Autoregression (VAR) yang menunjukkan bahwa t-hitung ekspor sebesar $-0.16093<$ dari t-tabel sebesar 1.71387. Artinya jika pertumbuhan ekonomi meningkat sebesar $1 \%$ maka pengangguran menurun sebesar -0.16093 Juta US\$.

4. Berdasarkan analisis Inpulse Response variabel pertumbuhan ekonomi membutuhkan waktu 3 sampai 4 tahun agar response pertumbuhan ekonomi kembali stabil akibat shock yang diberikan oleh inflasi, pengeluaran pemerintah dan ekspor.

5. Kemudian dengan analisis impluse respon variable inflasi terhadap pertumbuhan ekonomi dari tahun pertama sampai tahun ketiga menurun signifikan dan negatif serta tahun kelima mencapai titik kesimbangan atau equilibriumnya. Artinya butuh waktu empat tahun agar pertumbuhan ekonomi mengalami kestabilan setelah terjadi shock pada inflasi.

6. Respon pengeluaran pemerintah terhadap pertumbuhan ekonomi pada awal periode mengalami fluktuasi positif sampai tahun keempat dan mencapai titik keseimbangan pada tahun kelima. Kemudian respon pengeluaran pemerintah mengalami fluktuasi dari tahun keempat mengalami peningkatan sampai pada tahun kedelapan serta positif dari tahun kelima sampai tahun ke kesepuluh terhadap variabel itu sendiri. Artinya butuh waktu enam tahun agar pengeluaran pemerintah kembali stabil.

7. Respon ekspor terhadap pertumbuhan ekonomi pada awal periode mengalami fluktuasi sampai tahun kedelapan dan mencapai titik keseimbangan pada tahun kesembilan. Kemudian respon ekspor mengalami fluktuasi dari tahun pertama mengalami peningkatan hingga pada tahun ketiga serta positif dari tahun keempat sampai tahun ke sepuluh terhadap variabel itu sendiri. Artinya butuh waktu delapan tahun agar ekspor agar kembali stabil.

\section{Saran}

Berdasarkan kkesimpulan yang telah dikemukakan di atas maka yang menjadi saran dalam penelitian ini adalah:

1. Pemerintah Indonesia diharapkan dapat membuat kebijakan yang dapat menekan tingkat inflasi sehingga tidak sampai hiperinflasi melalui kebijakan fiscal dan kebijakan moneter.

2. Sebaiknya Pemerintah Indonesia meningkatkan pengeluaran/belanja negara yang bertujuan untuk mempercepat pembangunan ekonomi dan peningkatan kesejahteraan masyarakat Indonesia.

3. Pemerintah perlu memberikan perhatian yang lebih besar untuk bisa mengembangkan ekspor sehingga meningkatkan produksi yang akan membentuk nilai tambah bagi pertumbuhan ekonomi Indonesia.

4. Untuk Peneliti yang melakukan penelitian sejenis, penulis menyarankan agar menambah variabel lain yang mempengaruhi pertumbuhan ekonomi dan menggunakan metode penelitian lain dalam menganalisis data agar menjadi variasi dalam penelitian.

\section{DAFTAR PUSTAKA}

Antasari, \& Soleh. (2012). Pengaruh Pengeluaran Pemerintah Terhadap Pertumbuhan ekonomi di Provinsi bengkulu. Ekombis Review, 117127. Retrieved from http://jurnal.unived.ac.id/index.php/er/article/v iew/139

Ardiansyah, H. (2017). Pengaruh Inflasi terhadap Pertumbuhan ekonomi di Indonesia. Jurnal Pendidikan Ekonomi (JUPE), 5(3).

Bank, I. (2018). Memperkuat Ketahanan, Mendorong Momentum Pemulihan Ekonomi Nasional, Laporan Tahunan Bank Indonesia. statistik Ekonomi dan Keuangan Indonesia. Jakarta: Bank Indonesia.

Chtami, F. D. (2014). Analisis Pengaruh Jumlah Penduduk, Inflasi dan pengeluaran Pemerintah Terhadap Pertumbuhan Ekonomi Kota Surakarta Tahun 1991-2012. British Journal Of Psychiatry, 205(1).

Dewi, S. L. (2013). Pengaruh PAD, PMA, dan Inflsi terhadap Pertumbuhan Ekonomi Provinsi Bali. E-Jurnal Ekonomi Pembangunan Universitas Udayana, 2(11), 502-512. 
Indriyani, S. N. (2016). Analisis Pengaruh Inflasi dan Suku Bunga Terhadap Pertumbuhan Ekonomi di Indonesia Tahun 2005-2015. Jurnal Manajemen Bisnis Krisnadwipayana, 4(2).

Islamiah, N. (2015). Analisis Pengaruh Belanja Pembangunan/Modal dan Tingkat Inflasi Terhadap Pertumbuhan Ekonomi dan Penerimaan Pajak di Indonesia. Jurnal Eonomic, 3(1), 46-57.

Kristiawati. (2013). Pengaruh Ekspor, nilai Tukar, dan Inflasi Terhadap Pertumbuhan Ekonomi di Indonesia Taun 1995-2011. Jurnal Economic, 1(4).

Larasati, I. S., \& Sulastmiyati. (2018). Pengaruh Inflasi, Ekspor, dan Teaga Kerja Terhadap PDB. Jurnal Administrasi Bisnis (JAB), 63(1).

Lebang, Rotinsulu, \& Kawung. (2018). Analisis Pengaruh Pengeluaran Pemerintah dan Invetasi Swasta Terhadap Pertumbuhan Ekonomi di Kota Bitung. Jurnal Pembangunan Ekonomi Dan Keuangan Daerah, 19(1), 1-10.

Mankiw, N. G. (2006). Teori Makro Ekonomi Edisi Keenam. In Jakarta: Erlangga.

Pujoalwanto, B. (2014). Perekonomian Indonesia: Tinjauan Historis, Teoritis, dan Empiris. Yogyakarta: Graha Ilmu.

Sabtiadi, K., \& Kartikasari, D. (2018). Analisis Pengaruh Ekspor Impor Terhadap Nilai Tukar USD dan SGD. Jurnal Akuntansi, Ekonomi Dan Manajemen Bisnis, 6(2), 135141.

Safari, M. F. (2016). Analisis Pengaruh Utang Luar Negeri dan Pengeluaran Pemerintah Terhadap Pertumbuhan Ekonomi Indonesia. Jurnal Economic, 1(4).

Salhab, A., \& Soedjono, L. (2012). Pengaruh Inflasi, jumlah Tenaga Kerja, dan Pengeluaran Pemerintah Terhadap Pertumbuhan Ekonomi Bali. E-Jurnal Ekonomi Pembangunan Universitas Udayana, 2(1), 20-28.

Sukirno, S. (2000). Pengantar Teori Ekonomi Makro. In Jakarta: PT Raja Grafindo Persada.

Sukirno, S. (2010a). Makro Ekonomi. Jakarta: Grasindo Perseda.

Sukirno, S. (2010b). Makro Ekonomi. Teori Pengantar. Edisi ketiga. Jakarta: PT. Raja Grasindo Persada.

Sukirno, S. (2013). Makro Ekonomi Teori Pengantar. In Makro Ekonomi Teori Pengantar. Jakarta: PT. Raja Grafindo
Persada.

Tambunan. (2009). UMKN di Indonesia. Bogor: Ghalia Indonesia.

Todaro, M. (2003). Pembangunan Ekonomi Di Dunia Ketiga. Jilid 1. Jakarta: Erlangga.

Todaro, M. P. dan S. C. S. (2006). Pembangunan Ekonomi edisi 9. Jakarta: Erlangga.

Utomo, F. W. (2013). Pengaruh Inflasi dan Upah Terhadap Pengangguran Di Indonesia Periode Taun 1980-2010. Jurnal Ilmiah, 1(2).

Widarjono, A. (2018). Ekonometrika edisi keempat. Yogyakarta: UPP STIM YKPN. 